\title{
ANATOMY AND SYSTEMATICS OF ANODONTITES ELONGATUS (SWAINSON) FROM AMAZON AND PARANÁ BASINS, BRAZIL (MOLLUSCA, BIVALVIA, UNIONOIDA, MYCETOPODIDAE)
}

\author{
Luiz Ricardo L. Simone ${ }^{1}$
}

\begin{abstract}
The anatomy of Anodontites elongatus (Swainson, 1823), a rare species restricted to the Amazon and Paraná Basins, is described by first time, showing a group of conchological and anatomical characters exclusive of this species that may be analyzed to identify it. Diagnosis of A. elongatus: shell long antero-posteriorly, umbones prominent, periostracum opaque and smooth, two posterior radial striae; middle fold of mantle edge very tall; gill long antero-posteriorly and short dorso-ventrally, extending about a half of it total length beyond visceral mass; palps proportionally small, several furrows in its outer surface; stomach without esophageal transversal ridge, dorsal hood and gastric shield poorly developed, major typhlosole entering in $\mathrm{ddd}^{2}$, posterior pouch of $\mathrm{sa}^{3}$ very-long; style sac reduced, without crystalline style; distal region of intestine and rectum with a well developed typhlosole, "T" in section, other intestinal regions without folds; gonad gonochoristic.

KEY WORDS. Unionoida, Anodontites elongatus, anatomy, systematics, Brazil
\end{abstract}

Anodontites elongatus (Swainson, 1823) was described in the genus Anodon Oken, 1815, based on a single valve with the dubious provenance "South America". As main characters were given the antero-posterior elongation and the prominent umbones.

Probably due to its singular conchological characters and rarity, Anodontites elongatus has few synonyms for a Mycetopodidae, and has been rarely cited in the recent literature.

Several specimens identified as A. elongatus, were collected by the author and by the team of biologists and students of Prof. Thomaz Lipparelli of the Universidade para o Desenvolvimento do Estado e Região do Pantanal (UNIDERP), in the Pantanal. The study of these specimens permitted to amplify the knowledge on the species, mainly on anatomy, which is lacking in the literature, and to establish its identity.

This paper is the second of a series began by SIMONE (1994), on Anodontites trapesialis, with the objective of describing anatomically each Mycetopodidae species, giving base for future systematic and phylogenetic analyses.

1) Museu de Zoologia, Universidade de São Paulo. Caixa Postal 42694, 04299-970 São Paulo, São Paulo, Brazil.

E-mail: Irsimone@usp.br 


\section{MATERIAL AND METHODS}

Material Examined. BraziL, Mato Grosso do Sul: Corumbá (Medalha Bay, near Parque road, Passo do Lontra), MZUSP 28119, 25 specimens, 11/XII/1993; MZUSP 28120, 3 specimens, same local, 4/VI/1995; Miranda River, near Salobra River, MZUSP 28083, 1 specimen, 8/IX/1990, S.V. Leone leg.

The specimens were fixed in $70 \%$ ethanol, and were deposited in the Museu de Zoologia da Universidade de São Paulo (MZUSP) collection.

The specimens were dissected by standard technique, immersed in $70 \%$ ethanol. The inner surface of the stomachs were observed by means of a mediandorsal incision. Intestinal loops were observed in dissection of visceral mass and also by serial sections of $10 \mu \mathrm{m}$, using the normal histology technique, stained with Mallory.

Anatomical terminology is based on HEBLING (1976) and PURCHON (1958) referent to stomach. Anatomical comparisons with other Mycetopodidae species are based on VEITENHEIMER (1973a,b); MANSUR (1974), HEBLING (1976), VEITENHEIMER-MENDES \& MANSUR (1978), MANSUR \& Silva (1990), AVElar (1993) and SIMONE (1994).

In synonymic list (syn) means synonymy, (R) river. Only the more important localities are indicated.

Abbreviations. (am) anterior adductor muscle, (ap) anal papilla, (au) auricle, (ar) anterior retractor muscle of foot, (baa) anterior pouch of sorting area, (bap) posterior pouch of sorting area, (c) conical protuberance on floor of stomach, (cv) ctenidial vein, (da) anterior gastric fold, $\left(\mathrm{ddd}^{1}\right)$ orifice of left duct of digestive gland, $\left(\mathrm{ddd}^{2}\right)$ orifice of right duct of digestive gland, (dg) digestive gland (diverticula), (dh) dorsal hood, (ec) excurrent canal, (ft) foot, (go) gonad, (gs) gastric shield, (ic) incurrent canal, (id) inner demibranch, (in) intestinal loops, (ki) kidney, (lp) left pouch, (ls) ligament supporting gills, (mb) mantle border, (ne) nephrostome, (od) outer demibranch, (oe) esophagus, $(\mathrm{pa})$ posterior adductor muscle, $(\mathrm{pm})$ protractor muscle of foot, (po) posterior aorta, (pp) palps, (pr) posterior retractor muscle of foot, (r) dorsal ridge of stomach, (rt) rectum, (ry) rectal typhlosolis, (sb) shell border, (ss) style sac, (st) stomach, (tm) transversal muscles, (tr) transversal gastric ridge, (ty) major typhlosolis, (up) union between left and right mantle lobes, (ve) ventricle.

\section{Anodontites elongatus (Swainson, 1823)}

Anodon elongatus Swainson, 1823 (pl.176) [South America?].

Margarita (Anodonta) elongata; Lea, 1836: 53; 1838: 32.

Anodonta elongata; Hanley, 1842: 223; 1843: 223. - Adams \& Adams, 1857: 503.

Anodon elongata: Catlow \& Reeve, 1845: 66.

Anodonta solidula Deville \& Hupé, 1850: 644, pl.16, f.2. - Hupé, 1857: 88, pl.18, f.2 [Amazon]. - Adams \& Adams, 1857: 503. -Clessin, 1876: 221, pl.73, f.2. - Paetel, 1890: 185. - Simpson, 1900: 928 (syn). - Haas, 1931: 90 (syn).

Margaron (Anodonta) solidula; Lea, 1852b: 53; 1870:83.

Anodonta wheatleyi Lea, 1852a: 287: pl.26, f.49; 1952c: 43, pl.26, f.49. - Adams \& Adams, 1857: 503. - Clessin, 1874: 113, pl.36, f.3-4. - Hupé, 1857: 90, [Pará]. - Paetel, 1890: 186. - Simpson, 1900: 
928 (syn). - Haas, 1931: 90 (syn).

Margaron (Anodonta) wheatleyi; Lea, 1852b: 51; 1870: 82.

Anodonta schröteriana Lea, 1852a: 292, pl.29, f.55; 1852c: 48, pl.29, f.55. - Hupé, 1857: 89, pl.18, f.3

[Amazon]. - Adams \& Adams, 1857: 503. - Clessin, 1874: 151, pl.47, f.5-6. - Paetel, 1890: 184.

- Haas, 1931: 90 (syn).

Anodonta holtonis Lea, 1857a: 85; 1857b: 316, pl.32, f.31. -Clessin, 1874: 149, pl.50, f.5-6. - Wright, 1888. - Paetel, 1890: 180. - HAas, 1931: 90 (syn).

Margaron (Anodonta) schröteriana; Lea, 1852b: 51; 1870: 82.

Anodonta (Lamproscapha) weatleyi; Adams, 1866: 443 [Ucayali R., Peru].

Anodon dactylus Sowerby, 1867 (pl.19, f.75) [hab: ?]. - Simpson, 1900: 929 (syn). - Haas, 1931: 90 (syn).

Anodon schröteriana; Sowerby, 1868 (pl.20, f.77) [upper Amazon R.].

Anodon solidula; Sowerby, 1869 (pl.23, f.91) [Amazon R.].

Anodon amethystus Sowerby, 1869 (pl.24, f.95) [hab: ?]. - Simpson, 1900: 929 (syn). - Haas, 1931: 90 (syn).

Anodon haltonis; Sowerby, 1870 (pl.36, f.147) [near Cartago, New Grenada].

Margaron (Anodonta) holtonis; Lea, 1870: 79.

Margaron (Anodonta) dactylus; Lea, 1870: 80.

Anodonta amethysta; Clessin, 1875: 180, pl.60, f.3.

Anodonta dactylus; Clessin, 1875: 175, pl.62, f.3. - Paetel, 1890: 178.

Margaritana schröteriana; Paetel, 1890: 173.

Glabaris wheatleyi; Ihering, 1893: 120 [Amazonas basin].

Glabaris solidula; Ihering, 1893: 121 [Amazonas basin].

Glabaris holtonis; Simpson, 1900: 921.

Glabaris elongatus; Simpson, 1900: 928.

Glabaris schröterianus [sic]; Simpson, 1900: 931.

Anodontites (Anodontites) elongatus; Haas, 1931: 90 [Tatui R., SP; Mirim R., SP; Goiás; Amazonas; Popayan, Colombia; Magdalena R., Colombia]. - Schade, 1965: 121 [Guaira R., Paraguay].

Diagnosis. Shell long antero-posteriorly, umbones prominent, periostracum opaque and smooth, two posterior radial striae; middle fold of mantle edge very tall; gill long antero-posteriorly and short dorso-ventraly, extending about a half of it total length beyond visceral mass; palps proportionally small, several furrows in its outer surface; stomach without esophageal transversal ridge, dorsal hood and gastric shield poorly developed, major typhlosole entering in $\mathrm{ddd}^{2}$, posterior pouch of $\mathrm{sa}^{3}$ very-long; style sac reduced, without crystalline style; distal region of intestine and rectum with a well developed typhlosole, "T" in section, other intestinal regions without folds; gonad gonochoristic.

Description. Shell (Figs 1-3). Medium sized (to 60mm), antero-posteriorly long, elliptic outline, thick walled, somewhat rounded in section, dark-brown in color. Umbones somewhat outstanding, rounded, sited in anterior third part of ridge. Periostracum slight thick and opaque, lost near umbones. Sculpture lacking, except for concentric undulations, growth-lines and two conspicuous radial striae between mid and posterior regions of each valve. Hinge edentulous, ligament in all extension of ringe, thick in it mid and posterior regions; in posterior extremity a small triangular enlargement in each valve. Anterior scar elliptic, formed by adductor anterior retractor of foot muscles, protractor muscle of foot scar smaller and sited connected ventral and posterior to anterior adductor scar. Posterior adductor scar 
also elliptic, with an upper connected smaller scar of posterior retractor of foot. Dorsal or cardinal muscle scar missing. Pallial line simple. Nacre border somewhat narrow, of homogeneous width.
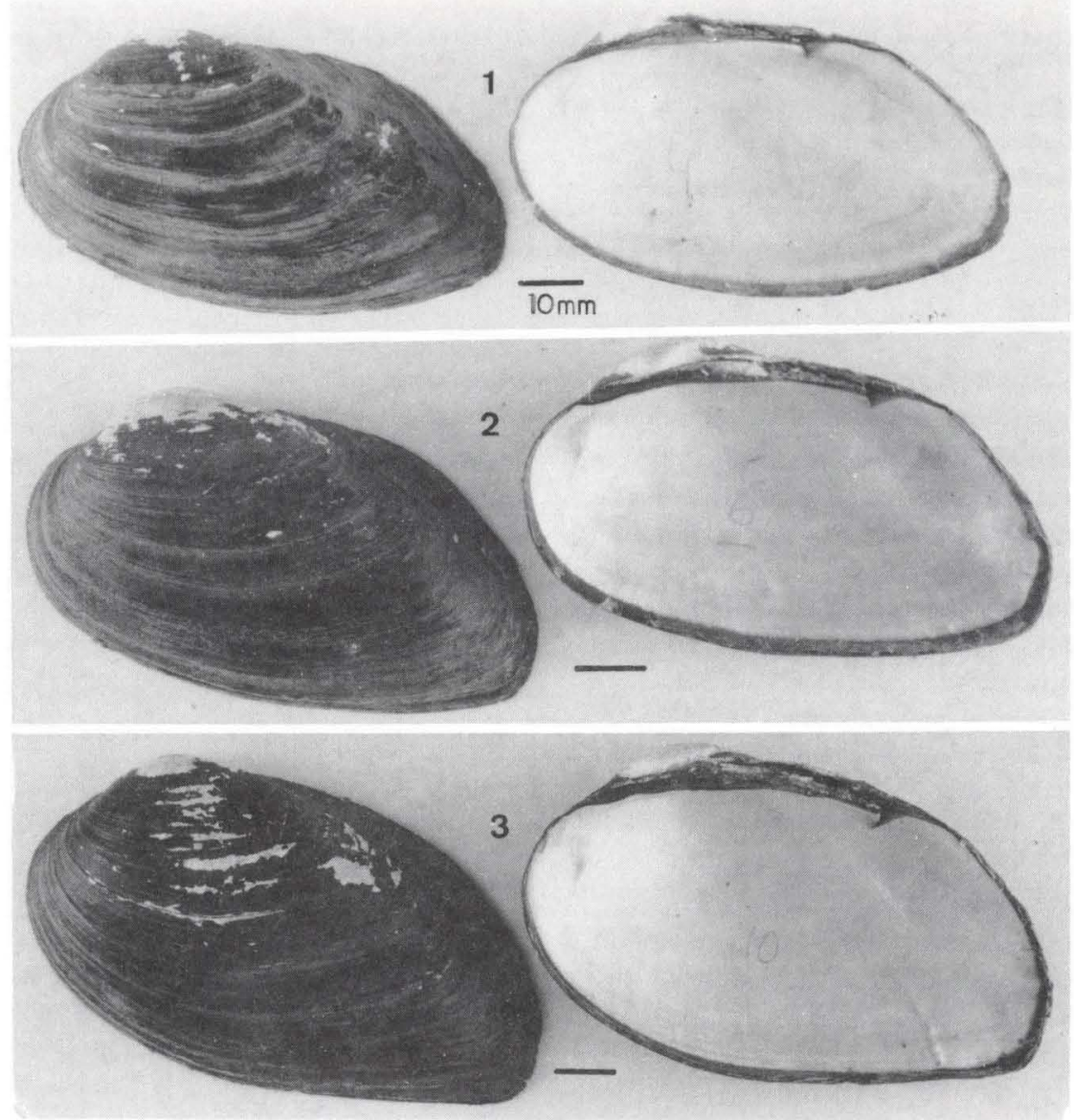

Figs 1-3. Samples of shell variation of Anodontites elongatus (MZUSP 28119). (1) Typical form, i.e., form of most part of specimens, an elliptic outline; (2) specimen with a sharp angle in posterior-ventral region; (3) largest collected specimen, very similar to literature figures of $A$. schroeteriana.

Mantle border. Simple, trifolded, without union except between incurrent and excurrent channels (Figs 4, 5: up). Tentacles small and simple, sometimes bifurcated, from incurrent channel into middle portion of ventral region, where gradually faint (Fig. 5); other regions without tentacles. In mid region of incurrent channel three pairs of tentacles slightly larger (Fig. 5). Color pale-cream with minute dark spots in exposed areas, mainly in posterior region. Middle fold of mantle edge very tall in all examined specimens (Fig. 19). 


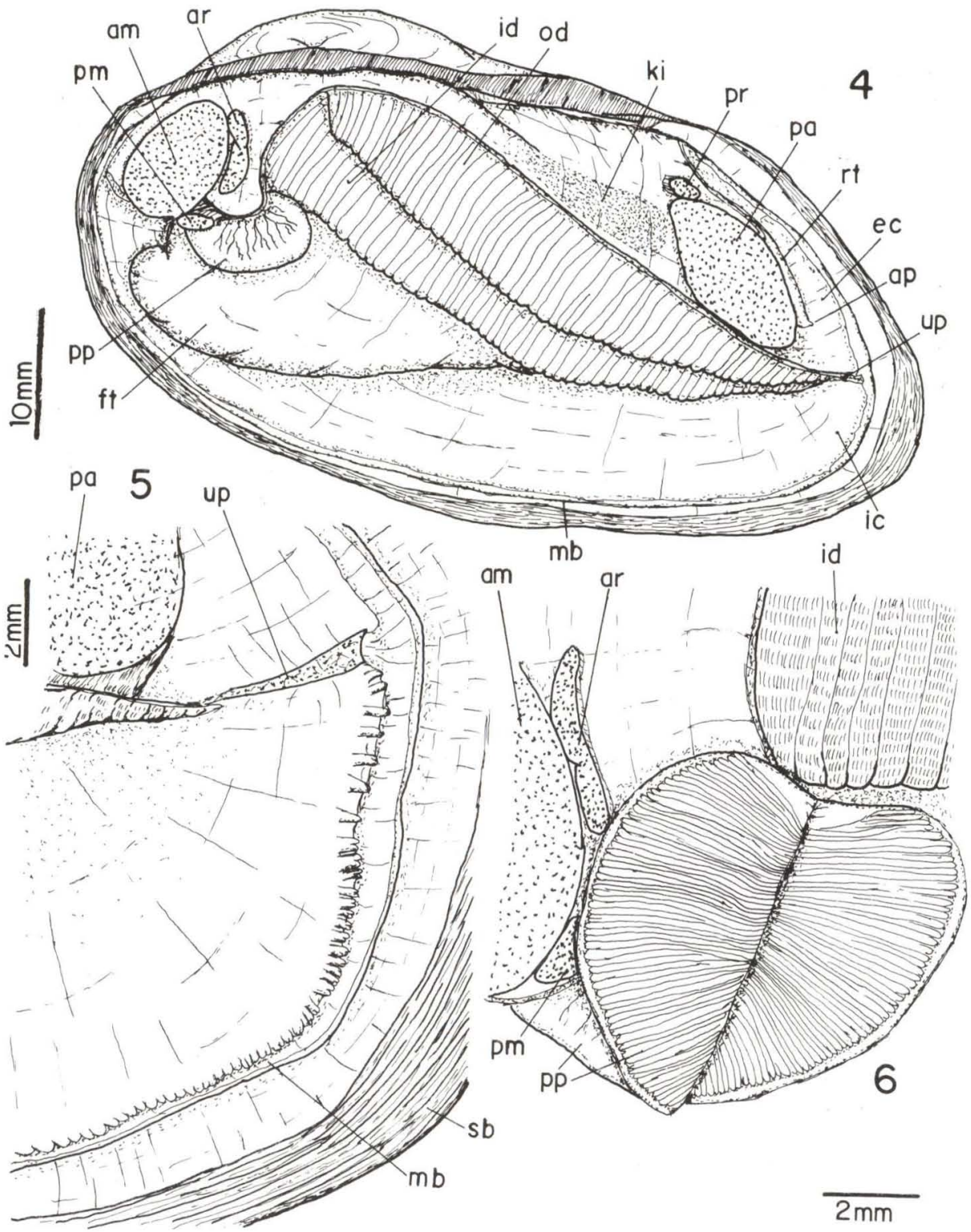

Figs 4-6, Anodontites elongatus anatomy. (4) Outer view of left region of pallial cavity, left mantle lobe partially removed; (5) detail of incurrent canal, left mantle lobe removed; (6) detail of left palp, outer hemipalp deflected to show inner folds.

Ctenidium. With strong transversal folds as normal mycetopodid (Fig. 4); folds discreetly broad and very numerous. Gill dorso-ventrally short, antero-posteriorly long, inner demibranch broader than outer demibranch (Fig. 4). Other 
characters, inclusive microscopic details of gill, as normal of family. Posterior region of gill beyond visceral mass, where left inner demibranch unites with right one, very long (about half of total gill length) (Figs 8, 10). Main vessel of ctenidium in its dorsal region (Fig. 10: cv) which bears several secondary vessels arranged, in both demibranchs, one each two transversal folds (Fig. 10).
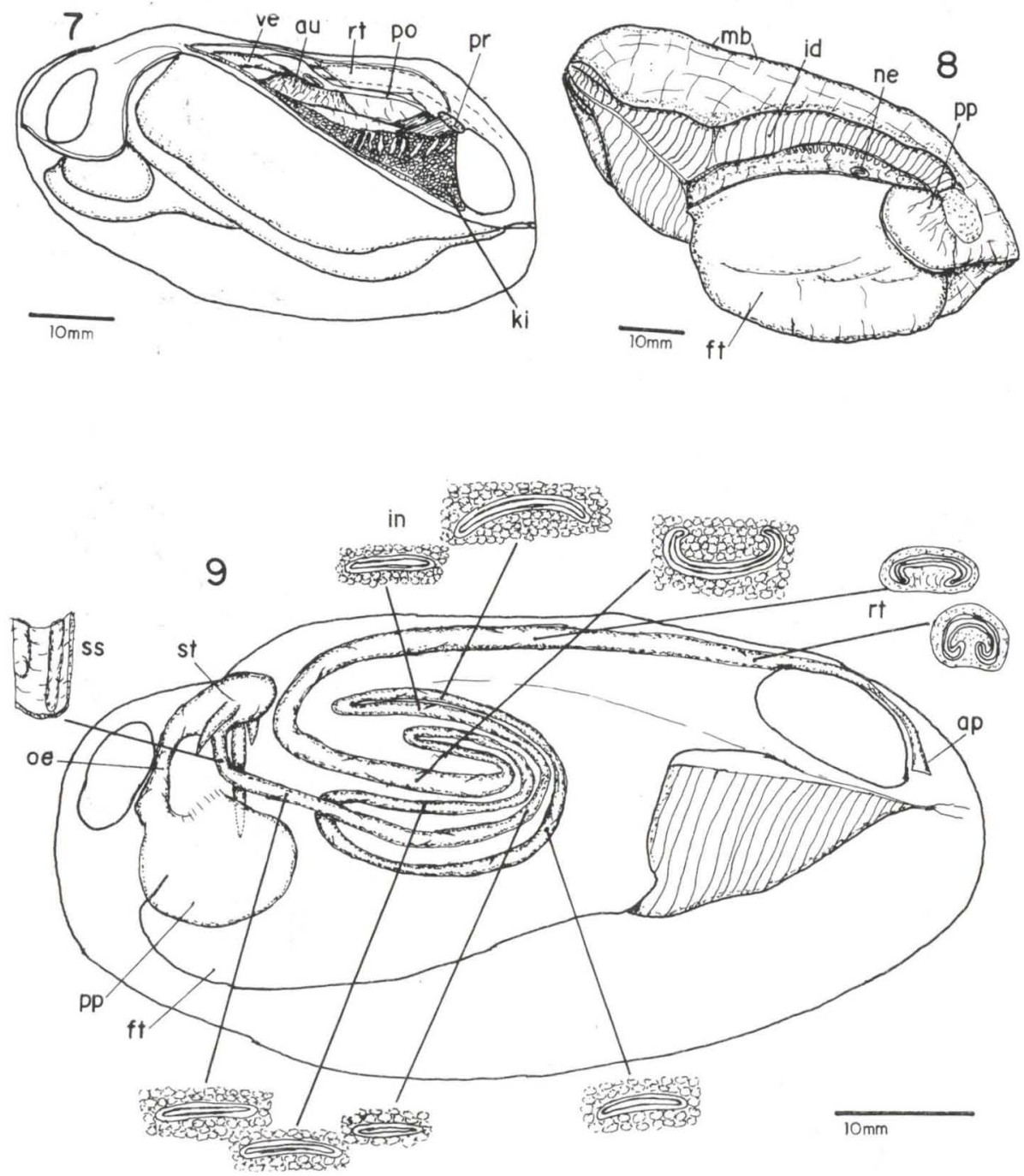

Figs 7-9. Anodontites elongatus anatomy. (7) Excretory and circulatory systems, left view, other structures schematically drawled; ( 8 ) nephrostome exposed by means of an incision in insertion of right inner demibranch in visceral mass, gill deflected; (9) scheme of digestive system ducts, left view, annexed a detail of style sac (ss) and sections of indicated parts of intestine and rectum. 


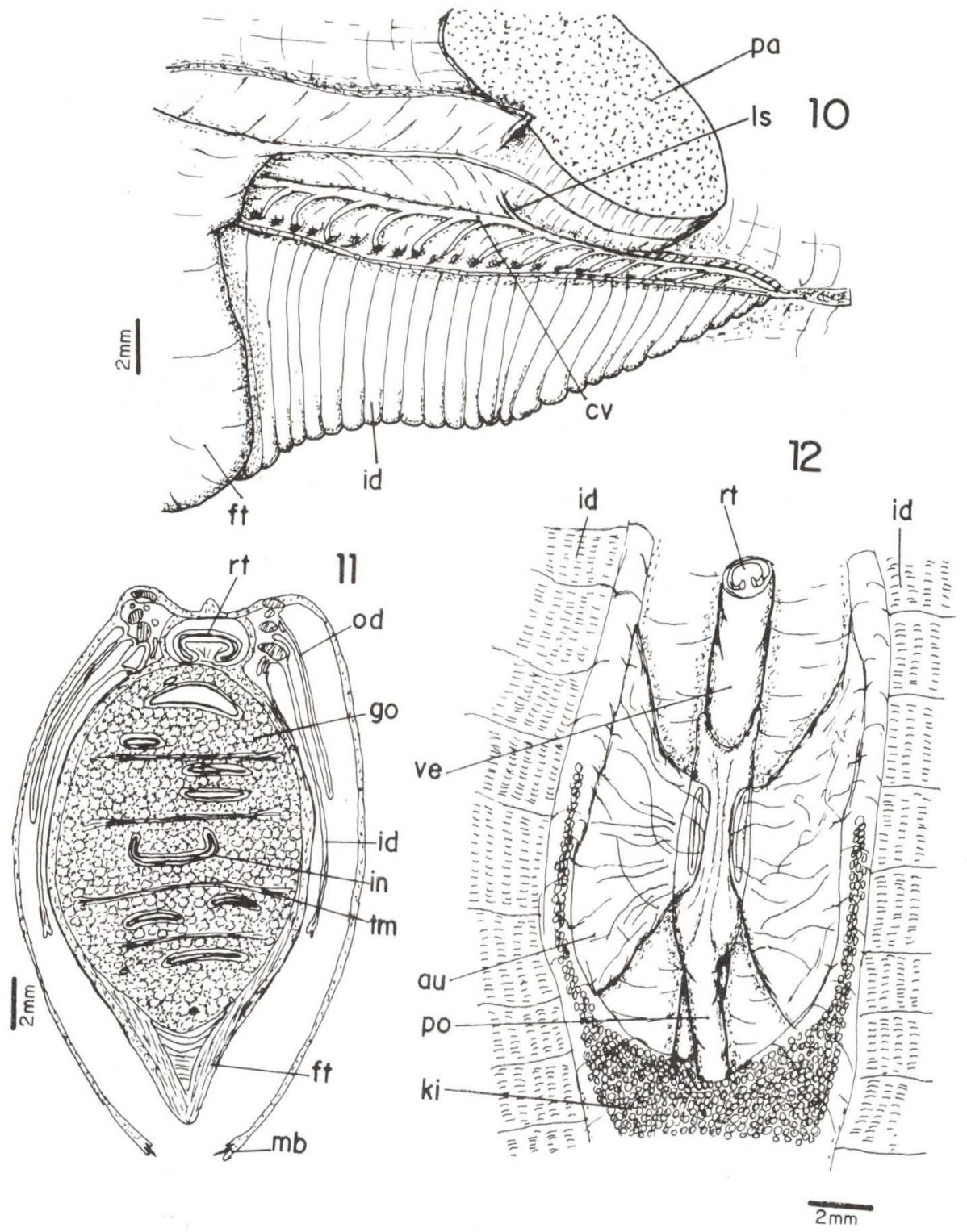

Figs 10-12. Anodontites elongatus anatomy. (10) Posterior region of mantle cavity, left view of right inner demibranch, left pallial organs removed; (11) section in mid region of visceral mass; (12) heart in ventral view, anterior region upper.

Digestive system. Palps proportionally small, with elliptic outline (Fig. 4); externally several irregular, shallow, radial furrows (Fig. 4); inner folds narrow, mainly visible by means of a microscope, finish near border, a inner smooth margin present (Fig. 6); profile of folds of palps shown in figure 18. Two small zones 


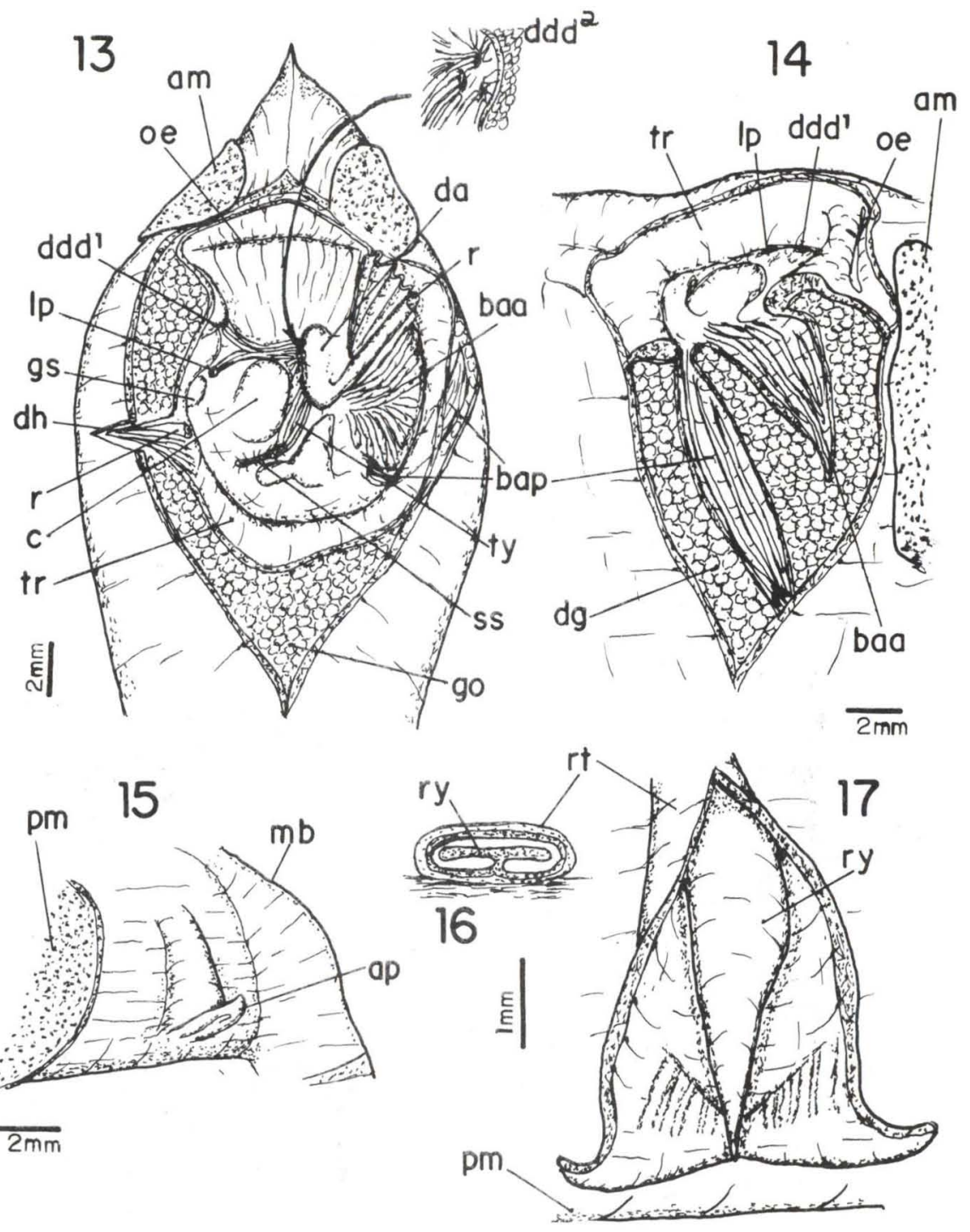

rigs 13-17, Anodontites elongatus anatomy. (13) Stomach in dorsal view, stomach dorsal wall deflected, dorsal mantle cover removed; (14) detail of stomach in lateral-right view, mantle cover and dorsal stomach wall removed; (15) detail of anal papilla, posterior view, right mantle lobe removed; (16) transversal section of rectum in region when it is exposed; (17) anal papilla opened longitudinally in its mid line.

without folds in anterior and posterior extremities of palps (Fig. 6). Month and short esophagus very-broad, about same width of anterior adductor muscle (Fig. 9). Esophagus internally with smooth surface, without transverse rim. Stomach (as normal unionoid) type IV by Purchon's (1958) classification (Figs 9, 13, 14). Minor 

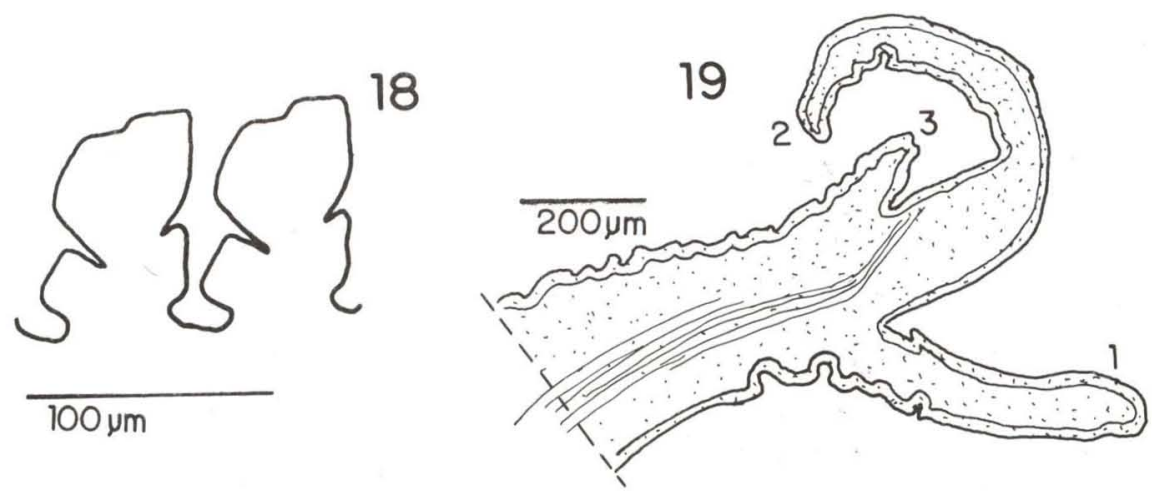

Figs 18-19. Anodontites elongatus details of serial sections. (18) Scheme of profile of two inner folds of palps, in its middle region; (19) mantle border showing the outer (1), mid (2) and inner (3) folds.

typhlosole (ty) difficult in being individualized, once several folds, of same size, run parallel to it, disappear anteriorly into right aperture of digestive gland $\left(\mathrm{ddd}^{2}\right)$. Two or three similar folds begin in this aperture and finish part in left aperture of digestive gland $\left(\mathrm{ddd}^{1}\right)$ and part in aperture of left pouch (Fig. 13). Into each digestive gland aperture, three ducts from digestive glands open. Upper cited folds penetrate into digestive gland ducts. Dorsal hood relatively far from other gastric structures, small, on left and mid side of stomach, internally longitudinal low folds (Fig. 13: $\mathrm{dh})$. Sorting area $\left(\mathrm{sa}^{3}\right)$ with two pouches, anterior (baa) broader and shorter than posterior pouch (bap), which is very-long, lying ventrally near foot dorsal limit (Figs $13,14)$; both sorting area pouches flattened, with several low, narrow, longitudinal folds in inner surface (Fig. 14). Other sorting areas not found. Anterior gastric fold (da) short, in it right-posterior region forms a ridge (r) which passes transversally in dorsal and mid-posterior region of gastric wall; this ridge finishes in right side near dorsal hood anterior limit; produces an anatomic esophageal chamber. Left pouch small, into which open two ducts from digestive gland. Gastric shield (gs) very-small and thin, with slightly homogeneous surface, without projections. On floor of stomach, in left side of intestinal groove (ss) a conspicuous, somewhat rounded mound (c) without annexed ridges. A thick ridge (tr) in almost entire circumference of stomach, except anterior, with a smooth surface; this ridge divides interior of stomach into dorsal and ventral compartments. Style sac very reduced, shown only by two small, short, shallow folds, in initial portion of intestine, afterwards intestine is a flattened tube without inner folds (Fig. 9: ss). Style not found. Other regions of intestine as normal mycetopodid, bearing four ample loops in visceral mass, inner folds lacking (Fig. 9). Terminal region of intestine, before rectum, very broad, with a median, voluminous and broad typhlosole, in its dorsal surface (Fig. 9). In rectum (Fig. 9: rt), base of this typhlosole (now in ventral surface) narrows gradually, becoming " $\mathrm{T}$ " in section; in region near posterior adductor muscle extremities of " $T$ " coil. In final region, near anal papilla, typhlosole is dorso-ventrally flattened and broad (Fig. 16), with a very-small base, tapers into 
ventral and middle limit of anal papilla (Fig. 17). Anal papilla bordered by thick walls (Fig. 15).

Visceral mass. Serial sections show digestive gland (diverticules) mainly distributed in anterior region near stomach, and gonochoristic gonad in mid and posterior regions (Fig. 11).

Excretory-circulatory systems. Both as normal Unionoida, and shown in figures 7 and 12. Kidney well-developed, dark colored, with a series of small, clear, outer glandular folds arranged transversally. Nephrostome in anterior region of dorsal border of inner demibranch (Fig. 8: ne). Heart proportionally short, sited in middle region of dorsal line (Fig. 7), auricle walls thin and transparent (Figs 7, 12). Ventricle valves slit-like, bordered by thick elevated walls (Fig. 12).

Range. Amazon and Paraná Basins, from Colombia to Uruguay.

Habitat. Little is known on the life-habits of this animal, the author only collect it twice, in a single day each, and in the literature no information about habitat is found. The specimens were found in shallow water (about $0.5 \mathrm{~m}$ deep), near surface of the sediment, which is a muddy sand, in a lake with slow current. It is interesting to note that generally the most common naiad in the South American collect sites are specimens of the genus Diplodon (Hyriidae), but no Diplodon was found in the local where occurs $A$. elongatus, which has a similar outline and size of the most Diplodon species. In the same local of A.elongatus were found A. trapesialis (Lamarck, 1819), Mycetopoda siliquosa (Spix, 1827) and Castalia sp. (several specimens of each), two specimens of Monocondylaea sp. and only one $A$. patagonicus (Lamarck, 1819).

Discussion. By antero-posterior elongation, Anodontites elongatus has some similarity with Anodontites obtusus (Spix, 1827) and A. trigonus (Spix, 1827), differs conchologically from both in having larger size, thick walls, umbones more outstanding and periostracum smooth (without reticulation). A.elongatus has some affinity also with species of the $A$. patagonicus group, differs by antero-posterior elongation.

The characters listed in the diagnosis differ A.elongatus from the other species of Mycetopodidae with known anatomy (see references cited in material and methods section). The main distinctive characters of the soft parts are stomach with poorly developed dorsal hood and gastric shield, posterior pouch of the sorting area $\mathrm{sa}^{3}$ very-long, style sac reduced with style missing and the "T" in section typhlosole of the rectum.

A.elongatus differs from Anodontites trapesialis (sensu SIMONE 1994) in having shell smaller, with thick walls and an elliptic outline; also in having gill and palps proportionally smaller; palps externally with several furrows, internally folds difficult to be seen, smooth inner area of the palps smaller; mantle without fourth fold, but with tentacles in incurrent canal; style sac reduced without style and inner structures; "T" shaped typhlosole in the rectum; anal papilla with thick walls; gonad gonochoristic and separated from the digestive gland.

The stomach of $A$. elongatus differs from the stomach of A.trapesialis (HEBLING 1976) in having: esophagus without transversal ridge; anterior fold shorter; transversal ridge in mid-dorsal gastric wall; dorsal hood poorly developed and far from the other gastric structures; posterior pouch of the sorting area $\left(\mathrm{sa}^{3}\right)$ 
very-longer; no other sorting area well developed; gastric shield poorly developed; protuberance of the floor rounded, without projections; major typhlosole small and with several similar folds in its sides, major typhlosole finishing in $\mathrm{ddd}^{2}$ (and not in ddd $^{1}$ ); separated folds from $\mathrm{ddd}^{2}$ into $\mathrm{ddd}^{1}$ and left pouch; absence of a fold around the aperture of the style sac.

ACKNOWLEDGMENTS. Special thank to Prof. Thomaz Lipparelli of the UNIDERP by the expedition to Pantanal; and Dr. Maria Cristina D. Mansur for personal communicated criticisms.

\section{REFERENCES}

ADAMS, H. 1866. List of land and freshwater shells collected by Mr. E. Bartlett on the upper Amazon, and on the river Ucayali, eastern Peru, with descriptions of new species. Proc. Zool. Soc. London: 440-445.

ADAMS, H. \& A. ADAMS. 1853-1858. The genera of recent Mollusca arranged acording to their organization. London, John von Voorst, Paternaster Row, vol. 1: 484p., vol. 2: 661p.

Avelar, W.E.P. 1993. Functional anatomy of Fossula fossiculifera (D'Orbigny, 1843) (Bivalvia: Mycetopodidae). Amer. Malac. Bull. 10 (2): 129-138.

Clatlow, A. \& L.A. REEVE. 1845. The conchologists nomenclator. A catalogue of all recent species of shells, included under the kingdon "Mollusca". London, I-VIII+326p.

Clessin, S. 1876. Die Gattung Anodonta nebst den übrigen Najaden mit unvoIlkommenem Schloss. Systematisches Conchylien Cabinet., Nürnberg, 9 (1): 65-287.

DEVILle, E. \& H. HuPÉ. 1850. Description de quelques coquilles neuvelles provenant de l'expedition de M. de Castelnau. Revue et Magasin de Zoologie 2 (2): 638-644.

HAAS, F. 1931. Versuch einer kritischen Sichtung der südamerikanischen Najaden III. Senckenbergiana 13 (2): 87-110.

HANLEY, S.C.T. 1842. Testaceous mollusca, Lamarck's species of shells. London, 244p.

-1842-1856. An illustrated and descriptive catalogue of recent bivalve shells, appendix to index testaceologicus. London, I-XVIII+392p.

HeBLING, N.J. 1976. The functional morphology of Anodontites trapezeus (Spix) and Anodontites trapesialis (Lamarck) (Bivalvia: Mycetopodidae). Bolm. Zool., São Paulo 1: 265-298.

HuPÉ, M.H. 1857. Mollusques (3). In: F. CASTELnAU (Ed.) Animaux nouveaux ou rares récuellis pedant l'expedition dans les parties centrales de l'Amerique du Sud, de Rio de Janeiro à Lima au Peru. Paris, 7 (3): 1-96.

IHERING, H. VON. 1893. Najaden von S. Paulo und die geographische Verbeitung der Süsswasserfauna von Südamerika. Arch. Nat. 59: 45-140.

LEA, I. 1836. A synopsis of the family of naiades. Philadelphia, I-VIII+59p. 1838. A synopsis of the family of naiades. Philadelphia, $2^{\text {nd }}, 44 p$. 1852a. Descriptions of new species of the family Unionidae. Trans. 
Amer. Phil. Soc. 10: 253-294.

$1852 \mathrm{~b}$. A synopsis of the family of naiades., third edition. Philadelphia, ed. by Blanchard \& Lea, I-XX+88.

1852c. Observations on the genus Unio. Philadelphia, vol. 5, 61p.

1857a. Descriptions of three new species of naiades. Proc. Acad. Nat.

Sci. Philadelphia 9: 85-86.

1857b. Descriptions of exotic genera and species of Unionidae. Jour.

Acad. Nat. Sci. Philadelphia 3: 289-321. $4^{\text {th }}, 184 \mathrm{p}$.

MANSUR, M.C.D. 1974. Monocondylaea minuana Orb., 1835, variabilidade da concha e morfologia do sistema digestivo (Bivalvia, Mycetopodidae). Iheringia, sér. Zoologia, 45: 3-25.

MANSUR, M.C.D. \& M.G.O. SilVA. 1990. Morfologia e microanatomia comparada de Bartlettia stephanensis (Moricand, 1856) e Anodontites tenebricosus (Lea, 1856) (Bivalvia, Unionoida, Muteloidea). Amazoniana 11 (2): 147-166.

PAETEL, F. 1890. Catalog der Conchylien-sammlung-vierte Neubearbeitungmit Hinzufügung der bis jetzt publicirten recenten Arten, sowie der ermittelten Synonyma. Dritte Abtheilung: die Acephalen und die Brachiopoden. Berlin, ed. by Verlag von G. Paetel 3: 1-253.

PURCHON, R.D. 1958. The stomach in the Eulamellibranchia; stomach type IV. Proc. Zool. Soc. London 131 (4): 487-525.

SCHADE, F.H. 1965. Lista de los moluscos del Guaira (Villarrica-Paraguay) conocidos hasta el presente. Comunic. Soc. Malac. Uruguay 1 (8): 209-221.

SimONE, L.R.L. 1994. Anatomical characters and systematics of Anodontites trapesialis (Lamarck, 1819) from South America (Mollusca, Bivalvia, Unionoida, Muteloidea). Stud. Neotrop. Fauna Environ. 29 (3): 169-185.

SiMPSON, C.T. 1900. Synopsis of the naiades, or pearly fresh-water mussels. Proc. U.S. Nat. Mus. 22 (2): 501-1075.

Sowerby, G.B. 1847-1887. Thesaurus Conchyliorum. London, 5 vols.

SWAINSON, W. 1822-1823. Zoological Illustrations, or original fugures and descriptions of new, rare, or interesting animals. London, James Moyes, 3, p.1-181.

VeITENHEIMER, I.L. 1973a. Contribuição ao estudo do gênero Leila Gray, 1840 (Mycetopodidae, Bivalvia). Iheringia, sér. Zoologia, 42: 64-89.

-1973b. Anodontites, Bruguière, 1792 no Guaiba, RS (Bivalvia, Mycetopodidae). I. Anodontites trapesialis forbesianus (Lea, 1960). Iheringia, sér. Zoologia, 44: 32-49.

VEITENHEIMER-MENDES, I.L. \& M.C.D. MANSUR. 1978. Morfologia, histologia e ecologia de Mycetopoda legumen (Martens, 1888) (Bivalvia, Mycetopodidae. Iheringia, sér. Zoologia, 52: 33-71.

WRIGHT, B.H. 1888. Check list of North American Unionidae, and other fresh water bivalves. Portland, $8 \mathrm{p}$.

Recebido em 25.VII.1996; aceito em 22.X.1997. 